\title{
Gangguan Fungsi Penghidu dan Pemeriksaannya
}

\author{
Effy Huriyati, Tuti Nelvia
}

\begin{abstract}
Abstrak
Latar belakang: Fungsi penghidu pada manusia memegang peranan penting. Gangguan penghidu dapat mempengaruhi keselamatan dan kualitas hidup seseorang. Tujuan: Untuk mengetahui jenis gangguan penghidu, penyebab gangguan penghidu, dan pemeriksaannya. Tinjauan Pustaka: Gangguan penghidu dapat berupa anosmia yaitu hilangnya kemampuan penghidu, atau hiposmia yaitu berkurangnya kemampuan penghidu. Gangguan penghidu disebabkan gangguan konduksi, gangguan sensoria dan gangguan neural. Penyakit tersering penyebab gangguan penghidu yaitu rinosinusitis kronis, rinitis alergi, infeksi saluran nafas atas dan trauma kepala. Ada beberapa modalitas pemeriksaan kemosensoris fungsi penghidu diantaranya Tes "Sniffin sticks". Dengan tes 'Sniffin sticks" dapat diketahui ambang penghidu, diskriminasi penghidu dan identifikasi penghidu seseorang. Kesimpulan: Gangguan penghidu memerlukan perhatian khusus. Diantara beberapa modalitas pemeriksaan kemosensoris penghidu, tes "Sniffin sticks" mempunyai beberapa kelebihan.
\end{abstract}

Kata kunci: Gangguan penghidu, anosmia, hiposmia, tes "Sniffin sticks".

\section{Abstract}

Background: Olfactory function in humans plays an important role. Olfactory disorders can affect the safety and quality of life. Objective: To determine the type of olfactory disorder, the causes of olfactory disorders, and the examination. Literature Review: Olfactory disorder can be not smell anything or anosmia, and reduced of smell or hyposmia. Olfactory disorders caused by conduction disturbances, neural disturbances and sensoris disturbances. Disease that often causes disturbances of olfactory function is, chronic rhinosinusitis, allergic rhinitis, upper respiratory tract infections and head trauma. There are several modalities to examine chemosensoris smelling function, one of them is "Sniffin sticks" test. This test can examine threshold, discrimination, and identification of smelling. Conclusions: Impaired smelling require special attention. Between some modalities to examine chemosensors smelling function, "Sniffin sticks" test has several advantages.

Keywords: Olfactory disorders, anosmia, hyposmia, "Sniffin sticks" test.

Affiliasi penulis : Fakultas Kedokteran Universitas Andalas, Korespondensi : Tuti Nelvia, email : tutinelvia@gmail.com, Telp: 08126724910

\section{PENDAHULUAN}

Fungsi penghidu pada manusia memiliki peranan penting. Gangguan penghidu dapat menyebabkan seseorang tidak dapat mendeteksi kebocoran gas, tidak dapat membedakan makanan basi, mempengaruhi selera makan, mempengaruhi psikis dan kualitas hidup seseorang. ${ }^{1,2,3}$

Insiden gangguan penghidu di Amerika

Serikat diperkirakan sebesar $1,4 \%$ dari jumlah penduduk. $^{2} \mathrm{Di}$ Austria, Switzerland, dan Jerman sekitar 80.000 penduduk pertahun berobat ke bagian THT dengan keluhan gangguan penghidu. ${ }^{4}$ Penyebab tersering gangguan penghidu adalah rinosinusitis kronik, rinitis alergi, infeksi saluran anafas atas dan trauma kepala.

Ada beberapa modalitas pemeriksaan kemosensoris fungsi penghidu, tapi jarang digunakan secara rutin di berbagai rumah sakit. Hal ini disebabkan harganya cukup mahal. ${ }^{1,2}$ Alat pemeriksaan kemosensoris fungsi penghidu yang berkembang dan banyak dipakai di negara Eropa seperti Jerman, Austria dan Switzerland adalah tes "Sniffin sticks". Tes ini dapat menilai 3 jenis tes yaitu ambang penghidu (treshold/T), diskriminasi penghidu (discrimination/D) dan identifikasi penghidu (identification/l). ${ }^{2,7}$
Anatomi dan fisiologi sistem penghidu.

Bagian dari fungsi penghidu yang terlibat adalah neuroepitel olfaktorius, bulbus olfaktorius dan korteks olfaktorius. , 8-13

\section{A. Neuroepitel olfaktorius}

Neuroepitel olfaktorius terdapat di atap rongga hidung, yaitu di konka superior, septum bagian superior, konka media bagian superior atau di dasar lempeng kribriformis. Neuroepitel olfaktorius merupakan epitel kolumnar berlapis semu yang berwarna kecoklatan, warna ini disebabkan pigmen granul coklat pada sitoplasma kompleks golgi. ${ }^{2,8,10}$ Regio neuroepitel olfaktorius (gambar 1 ). ${ }^{9}$

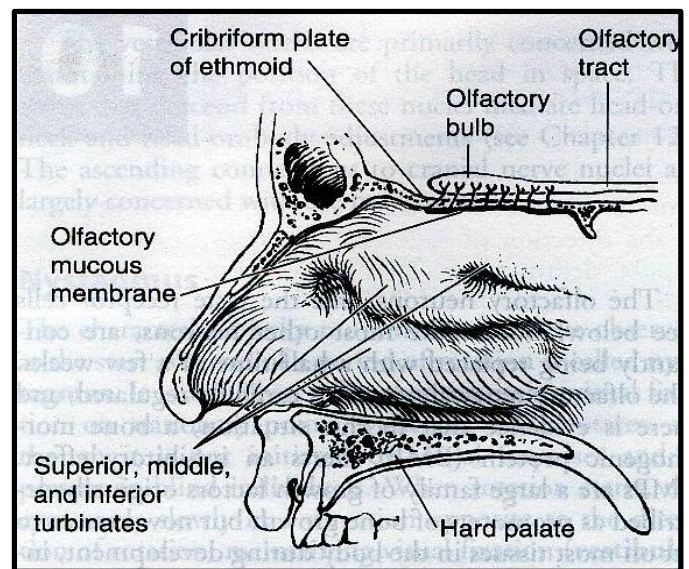

Gambar 1. Regio neuroepitel olfaktorius. 
Sel di neuroepitel olfaktorius ini terdiri dari sel pendukung yang merupakan reseptor olfaktorius. Terdapat 10-20 juta sel reseptor olfaktorius. Pada ujung dari masing-masing dendrit terdapat olfactory rod dan diujungnya terdapat silia. Silia ini menonjol pada permukaan mukus. ${ }^{11,12}$ Sel lain yang terdapat di neuroepitel olfaktorius ini adalah sel penunjang atau sel sustentakuler. Sel ini berfungsi sebagai pembatas antara sel reseptor, mengatur komposisi ion lokal mukus dan melindungi epitel olfaktorius dari kerusakan akibat benda asing.,11,13 Mukus dihasilkan oleh kelenjar Bowman's yang terdapat pada bagian basal sel olfaktoris. ${ }^{11}$ Membran mukus dari neuroepitel olfaktorius (gambar 2). ${ }^{9}$

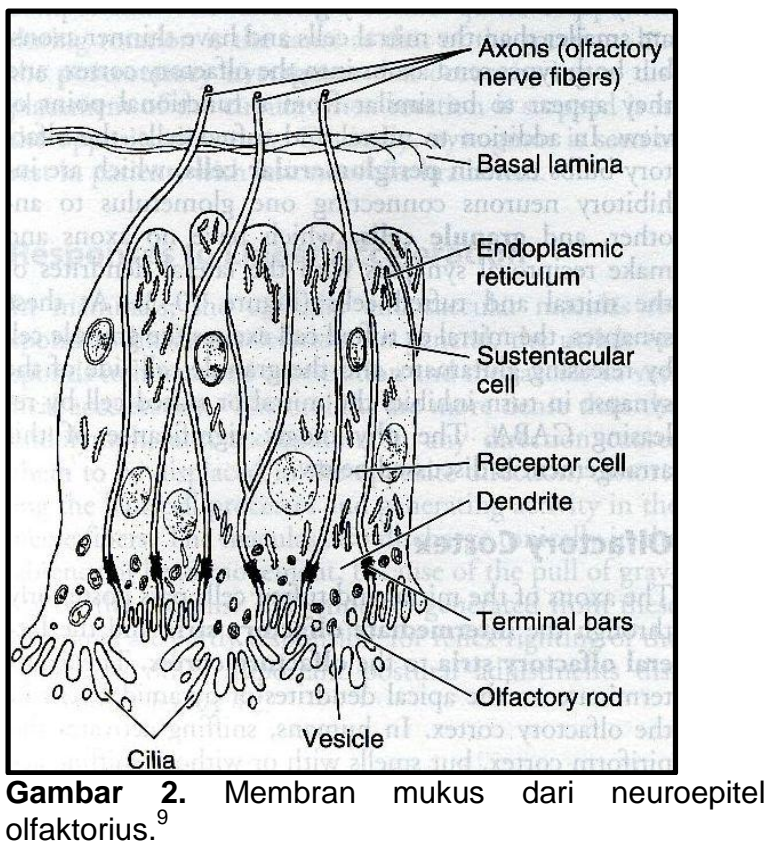

Melalui proses inhalasi udara, odoran sampai di area olfaktorius, kemudian bersatu dengan mukus yang terdapat di neuroepitel olfaktorius dan berikatan dengan reseptor protein $\mathrm{G}$ yang terdapat pada silia. ${ }^{9,12}$ Ikatan protein $G$ dengan reseptor olfaktorius ( $G$ protein coupled receptors) akan mengaktifkan enzim adenylyl cyclase yang merubah adenosine triphosphate (ATP) menjadi cyclic adenosine monophosphate (cAMP) yang merupakan second messenger. Hal ini akan menyebabkan aktivasi sel dengan terbukanya pintu ion yang menyebabkan masuknya natrium $(\mathrm{Na}+)$ dan kalsium (Ca2+) ke dalam sel sehingga terjadi depolarisasi dan penjalaran impuls ke bulbus olfaktorius. ${ }^{2,10,12}$ Aktivasi reseptor sel olfaktorius (gambar 3). ${ }^{12}$

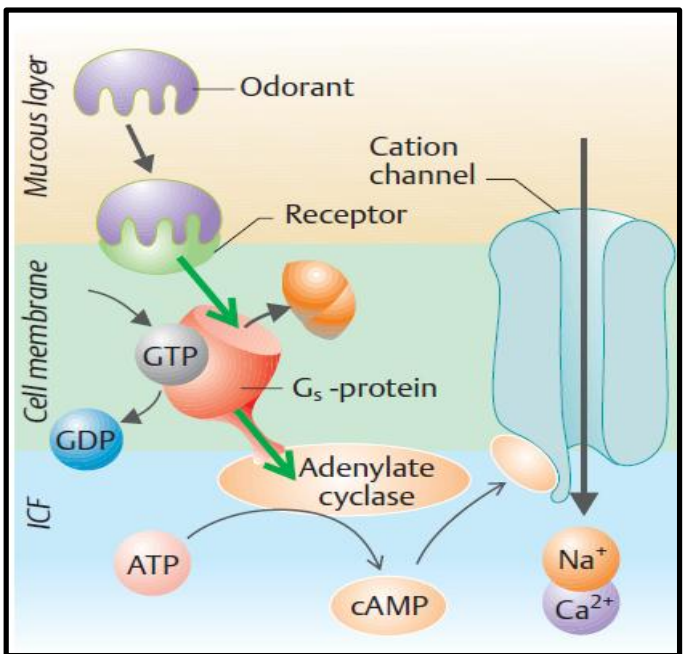

Gambar 3. Aktivasi reseptor sel olfaktorius.

B. Bulbus olfaktorius

Bulbus olfaktorius berada di dasar fossa anterior dari lobus frontal. ${ }^{12}$ Bundel akson saraf penghidu (fila) berjalan dari rongga hidung dari lempeng kribriformis diteruskan ke bulbus olfaktorius. Dalam masing-masing fila terdapat 50 sampai 200 akson reseptor penghidu pada usia muda, dan jumlah akan berkurang dengan bertambahnya usia. ${ }^{2,10,11}$ Akson dari sel reseptor yang masuk akan bersinap dengan dendrit dari neuron kedua dalam gromerulus. Perjalanan impuls di bulbus olfaktorius (Gambar 4).

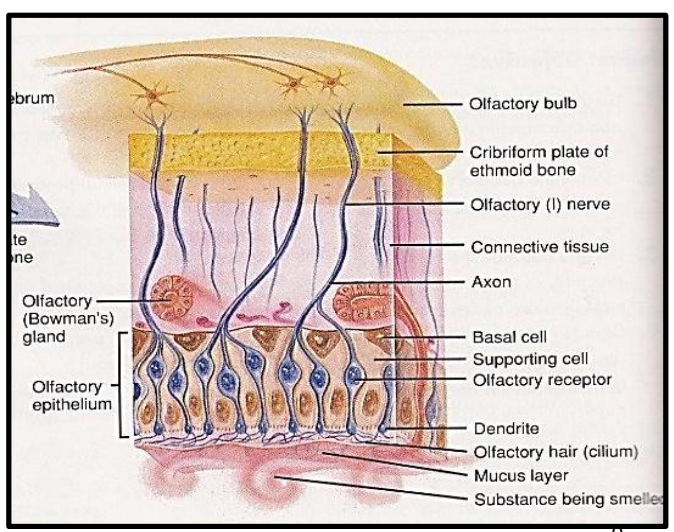

Gambar 4. Perjalanan impuls di bulbus olfaktorius.

C. Korteks olfaktorius

Terdapat 3 komponen korteks olfaktorius, yaitu pada korteks frontal merupakan pusat persepsi terhadap penghidu. ${ }^{10}$ Pada area hipotalamus dan 
amygdala merupakan pusat emosional terhadap odoran, dan area enthorinal merupakan pusat memori dari odoran. ${ }^{9,10}$ Korteks olfaktorius (gambar 5). ${ }^{9}$

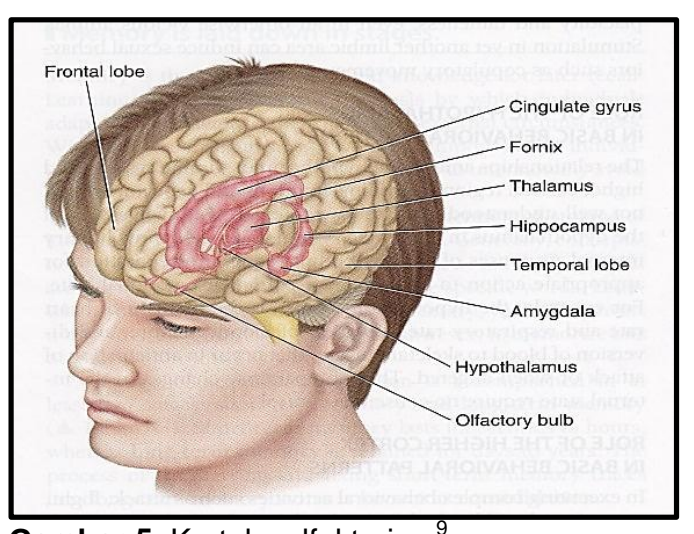

Gambar 5. Korteks olfaktorius.

Saraf yang berperan dalam sistem penghidu adalah nervus olfaktorius ( $\mathrm{N}$ I). Filamen saraf mengandung jutaan akson dari jutaan sel-sel reseptor. ${ }^{2,8}$ Satu jenis odoran mempunyai satu reseptor tertentu, dengan adanya nervus olfaktorius kita bisa mencium odoran seperti strawberi, apel dan bermacam odoran lain. ${ }^{8,10,11}$

Saraf lain yang terdapat di hidung adalah saraf somatosensori trigeminus $(\mathrm{N} V)$. Letak saraf ini tersebar diseluruh mukosa hidung dan kerjanya dipengaruhi rangsangan kimia maupun nonkimia. Kerja saraf trigeminus tidak sebagai indera penghidu tapi menyebabkan seseorang dapat merasakan stimuli iritasi, rasa terbakar, rasa dingin, rasa geli dan dapat mendeteksi bau yang tajam dari amoniak atau beberapa jenis asam. Ada anggapan bahwa nervus olfaktorius dan nervus trigeminus berinteraksi secara fisiologis. $^{2,5}$

Saraf lain yang terdapat dihidung yaitu sistem saraf terminal ( $\mathrm{N} \mathrm{O}$ ) dan organ vomeronasal (VMO). Sistem saraf terminal merupakan pleksus saraf ganglion yang banyak terdapat di mukosa sebelum melintas ke lempeng kribriformis. Fungsi saraf terminal pada manusia belum diketahui pasti. Organ rudimeter vomeronasal disebut juga organ Jacobson's. Pada manusia saraf ini tidak berfungsi dan tidak ada hubungan antara organ ini dengan otak. Pada pengujian elektrofisiologik, tidak ditemukan adanya gelombang pada organ ini. ${ }^{2,8,10}$

\section{Gangguan penghidu}

Kemampuan penghidu normal didefinisikan sebagai normosmia. ${ }^{2}$ Gangguan penghidu dapat berupa: ${ }^{14-17}$

A. Anosmia yaitu hilangnya kemampuan menghidu.

B. Agnosia yaitu tidak bisa menghidu satu macam odoran.

C. Parsial anosmia yaitu ketidak mampuan menghidu beberapa odoran tertentu.

D. Hiposmia yaitu penurunan kemampuan menghidu baik berupa sensitifitas ataupun kualitas penghidu.

E. Disosmia yaitu persepsi bau yang salah, termasuk parosmia dan phantosmia. Parosmia yaitu perubahan kualitas sensasi penciuman, sedangkan phantosmia yaitu sensasi bau tanpa adanya stimulus odoran/ halusinasi odoran.

F. Presbiosmia yaitu gangguan penghidu karena umur tua.

\section{Penyebab gangguan penghidu.}

Penyebab gangguan penghidu dapat diklasifikasikan menjadi 3, yaitu gangguan konduktif, gangguan sensoris dan gangguan neural. Gangguan konduktif disebabkan gangguan transpor odoran atau pengurangan odoran yang sampai ke neuroepitel olfaktorius, dan gangguan ikatan odoran dengan protein G (golf). Gangguan sensoris disebabkan kerusakan langsung pada neuroepitelium olfaktorius, misalnya pada infeksi saluran nafas atas, atau polusi udara toksik, sedangkan gangguan neural atau saraf disebabkan kerusakan pada bulbus olfaktorius dan jalur sentral olfaktorius, misalnya pada penyakit neurodegeneratif, atau tumor intrakranial. ${ }^{11,13,15}$

Penyakit yang sering menyebabkan gangguan penghidu adalah penyakit rinosinusitis kronik, rinitis alergi, infeksi saluran nafas atas dan trauma kepala. ${ }^{11,14,18-21}$

A. Penyakit rinosinusitis kronik dan rinitis alergi.

Gangguan penghidu pada rinosinusitis kronik atau rinitis alergi berupa gangguan penghidu konduktif dan sensoris. Gangguan penghidu konduktif terjadi karena proses inflamasi dari saluran nafas yang menyebabkan berkurangnya aliran udara dan odoran yang sampai ke neuroepitel olfaktorius. Proses inflamasi pada neuroepitel olfaktorius menghasilkan mediator inflamasi yang merangsang hipersekresi dari kelenjar Bowman's, yang akan mengubah konsentrasi ion pada mukus olfaktorius, sehingga mengganggu hantaran odoran. Gangguan penghidu sensoris disebabkan pelepasan mediator inflamasi oleh limfosit, makrofag, dan eosinofil, yang bersifat toksik terhadap reseptor neuroepitel olfaktorius sehingga menyebabkan kerusakan neuroepitel olfaktorius. ${ }^{11,14}$ B. Infeksi saluran nafas atas.

Penyakit infeksi saluran nafas atas yang sering menyebabkan gangguan penghidu adalah common cold. Kemungkinan mekanismenya adalah kerusakan langsung pada epitel olfaktorius atau jalur sentral karena virus itu sendiri yang dapat merusak sel reseptor olfaktorius. Prevalensi gangguan penghidu yang disebabkan oleh infeksi saluran nafas atas \pm 11 $40 \%$ dari kasus gangguan penghidu. ${ }^{14,18}$

\section{Trauma kepala}

Trauma kepala dapat menyebabkan kehilangan sebagian atau seluruh fungsi penghidu. Hal ini disebabkan kerusakan pada epitel olfaktorius dan gangguan aliran udara dihidung. Adanya trauma menyebabkan hematom pada mukosa hidung, atau luka pada epitel olfaktorius. Kerusakan dapat terjadi pada serat saraf olfaktorius, bulbus olfaktorius dan kerusakan otak di regio frontal, orbitofrontal, dan temporal. Prevalensi gangguan penghidu yang disebabkan trauma kepala terjadi $\pm 15-30 \%$ dari kasus gangguan penghidu. ${ }^{11,14,19}$

Hasil penelitian Chang $^{20}$ pada pasien rinosinusitis kronik didapatkan $21 \%-25 \%$ anosmia. Guilermany $^{21}$ mendapatkan pasien dengan rinitis alergi persisten sedang berat yang mengalami hiposmia sebesar $84,8 \%$, dan rinitis alergi persisten ringan yang mengalami hiposmia sebesar $20 \%$.

Penyakit lain yang menyebabkan gangguan penghidu adalah penyakit endokrin (hipotiroid, diabetes melitus, gagal ginjal, penyakit liver), Kallmann syndrome, penyakit degeneratif (alzheimer, parkinson, multipel sklerosis), pasca laringektomi, paparan terhadap zat kimia toksik, peminum alkohol, skizofrenia, tumor intranasal atau intrakranial. ${ }^{2,22}$ 
Faktor lain yang juga berpengaruh terhadap fungsi penghidu adalah usia. Kemampuan menghidu akan menurun sejalan dengan bertambahnya usia. Ada banyak teori yang menerangkan penyebab gangguan penghidu pada orang tua, diantaranya terjadi perubahan anatomi pengurangan area olfaktorius, pengurangan jumlah sel mitral pada bulbus olfaktorius, penurunan aktivasi dari korteks olfaktorius. ${ }^{2,10}$ Gangguan penghidu pada usia lebih dari 80 tahun sebesar $65 \% .{ }^{23}$ Penelitian lain mendapatkan gangguan penghidu pada usia lebih dari 50 tahun sebesar 24\%. ${ }^{22}$ Doty $^{2}$ menyatakan terdapatnya penurunan penghidu yang signifikan pada usia lebih dari 65 tahun.

Ganguan penghidu lebih sering ditemukan pada jenis kelamin perempuan dibandingkan laki-laki. ${ }^{4}$ Pada penelitian Rouby ${ }^{16}$ ditemukan gangguan penghidu hiposmia ditemukan pada $61 \%$ wanita dan $39 \%$ laki-laki.

Gangguan penghidu juga ditemukan pada perokok, dimana ditemukan kerusakan neuroepitel olfaktorius. Pada analisis imunohistokimia ditemukan adanya apoptosis proteolisis pada neuroepitel olfaktorius. ${ }^{4,24}$

Obat-obatan juga berpengaruh terhadap terjadinya gangguan penghidu seperti obat golongan makrolide, anti jamur, protein kinase inhibitor, ACE inhibitor, dan proton pump inhibitor. Ada beberapa mekanisme yang menyebabkan gangguan penghidu seperti gangguan potensial aksi dari sel membran, gangguan pada neurotransmitter dan perubahan pada permukaan mukus. ${ }^{25}$ Polusi udara yang berpengaruh terhadap gangguan penghidu misalnya pada udara yang mengandung aseton, gas nitrogen, silikon dioksida dan nikel dioksida. ${ }^{2}$

\section{Pemeriksaan fungsi penghidu}

\section{A. Anamnesis}

Anamnesis sangat diperlukan untuk membantu menegakkan diagnosis gangguan penghidu. Pada anamnesis ditanyakan riwayat trauma kepala, penyakit sinonasal, dan infeksi saluran nafas atas, riwayat penyakit sistemik, riwayat penyakit neurodegeneratif, kebiasaan merokok, dan semua faktor yang bisa menyebabkan gangguan penghidu. 2,12,16

B. Pemeriksaan fisik

Pemeriksaan fisik THT meliputi pemeriksaan hidung dengan rinoskopi anterior, posterior dan nasoendoskopi untuk menilai ada atau tidaknya sumbatan di hidung, seperti inflamasi, polip, hipertrofi konka, septum deviasi, penebalan mukosa, dan massa tumor akan mempengaruhi proses transport odoran ke area olfaktorius. ${ }^{2,5,10,23}$

C. Pemeriksaan pencitraan.

Pemeriksaan ini bertujuan untuk menyingkirkan kelainan intrakranial dan evaluasi kondisi anatomis dari hidung, misalnya pada kasus tumor otak atau kelainan dihidung. Pemeriksaan foto polos kepala tidak banyak memberikan data tentang kelainan ini. Pemeriksaan tomografi komputer merupakan pemeriksaan yang paling berguna untuk memperlihatkan adanya massa, penebalan mukosa atau adanya sumbatan pada celah olfaktorius.
Pemeriksaan Magnetic Resonance Imaging (MRI) merupakan pemeriksaan yang lebih sensitif untuk kelainan pada jaringan lunak. Pemeriksaan ini dilakukan bila ada kecurigaan adanya tumor. ${ }^{2,13,16}$

D. Pemeriksaan kemosensoris penghidu

Pemeriksaan kemosensoris penghidu yaitu pemeriksaan dengan menggunakan odoran tertentu untuk merangsang sistem penghidu. Ada beberapa jenis pemeriksaan ini, diantaranya tes UPSIT (University of Pennsylvania Smell Identification), Tes The Connectitut Chemosensory Clinical Research Center (CCCRC), Tes "Sniffin sticks", Tes Odor Stick Identification Test for Japanese (OSIT-J).

1. Tes UPSIT (University of Pennsylvania Smell Identification).

Test ini berkembang di Amerika, pada tes ini terdapat 4 buku yang masing-masing berisi 10 odoran. $^{2}$ Pemeriksaan dilakukan dengan menghidu buku uji,

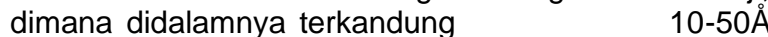
odoran. Hasilnya pemeriksaan akan dibagi menjadi 6 kategori yaitu normosmia, mikrosmia ringan, mikrosmia sedang, mikrosmia berat, anosmia, dan malingering. ${ }^{2,26}$

\section{Tes The Connectitut Chemosensory Clinical} Research Center (CCCRC).

Test ini dapat mendeteksi ambang penghidu, identifikasi odoran, dan untuk evaluasi nervus trigeminal. Ambang penghidu menggunakan larutan butanol $4 \%$ dan diencerkan dengan aqua steril dengan perbandingan $1: 3$, sehingga didapat 8 pengenceran. Tes dimulai dari pengenceran terkecil, dan untuk menghindari bias pasien disuruh menentukan mana yang berisi odoran tanpa perlu mengidentifikasikannya. Ambang penghidu didapat bila jawaban betul 5 kali berturut-turut tanpa kesalahan. Pemeriksaan dikerjakan bergantian pada hidung kiri dan kanan, dengan menutup hidung kiri bila memeriksa hidung kanan atau sebaliknya. ${ }^{2,27}$ Kemudian dilakukan tes identifikasi penghidu, dengan menggunakan odoran kopi, coklat, vanila, bedak talk, sabun, oregano, dan napthalene. Nilai ambang dan identifikasi dikalkulasikan dan dinilai sesuai skor CCCRC. 2,20,27,28

3. Tes "Sniffin Sticks".

Tes Sniffin Sticks adalah tes untuk menilai kemosensoris dari penghidu dengan alat yang berupa pena. Tes ini dipelopori working group olfaction and gustation di Jerman dan pertama kali diperkenalkan oleh Hummel ${ }^{29}$ dan kawan-kawan. Tes ini sudah digunakan pada lebih dari 100 penelitian yang telah dipublikasikan, juga dipakai di banyak praktek pribadi dokter di Eropa.

Panjang pena sekitar $14 \mathrm{~cm}$ dengan diameter $1,3 \mathrm{~cm}$ yang berisi $4 \mathrm{ml}$ odoran dalam bentuk tampon dengan pelarutnya propylene glycol. ${ }^{7}$ Alat pemeriksaan terdiri dari tutup mata dan sarung tangan yang bebas dari odoran dan pena untuk tes identifikasi (Gambar 6). ${ }^{31}$ Keseluruhan pena berjumlah 16 triplet (48 pena) untuk ambang penghidu, 16 triplet (48 pena) untuk diskriminasi penghidu, dan 16 pena untuk identifikasi penghidu, sehingga total berjumlah 112 pena (gambar 7$)^{32}$ 


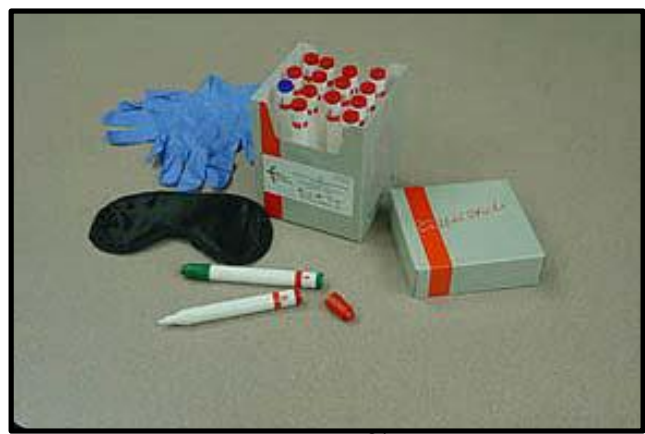

Gambar 6. Alat tes "Sniffin Sticks".

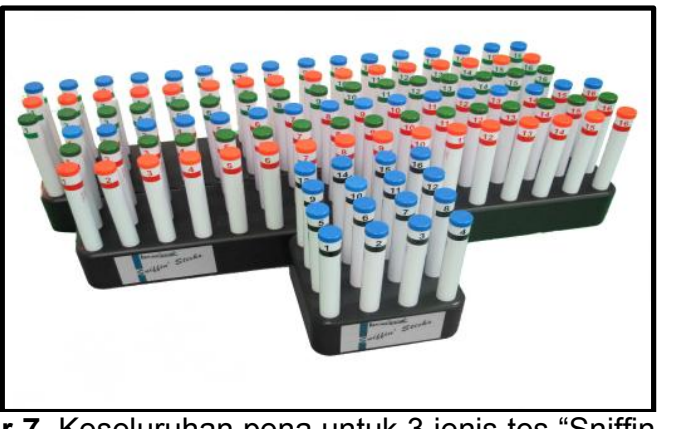

Gambar 7. Keseluruhan pena untuk 3 jenis tes "Sniffin sticks". 32

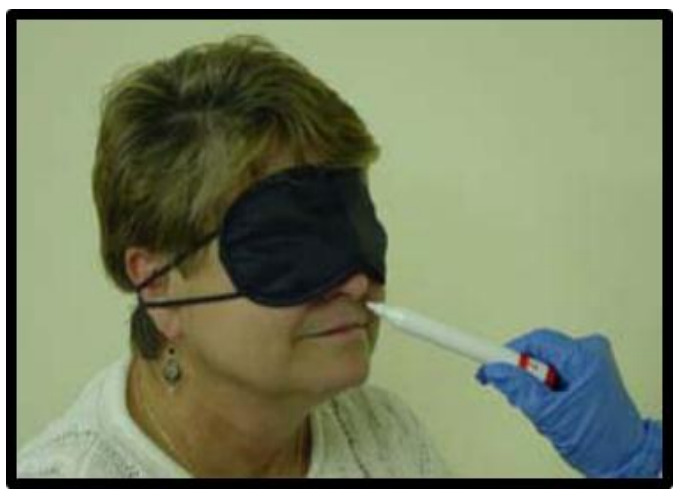

Gambar 8. Cara melakukan test "Sniffin sticks". 31

Pengujian dilakukan dengan membuka tutup pena selama 3 detik dan pena diletakkan $2 \mathrm{~cm}$ di depan hidung, tergantung yang diuji apakah lobang hidung kiri atau lobang hidung kanan (gambar 10). ${ }^{33}$ Pemeriksaan dilakukan dengan menutup mata subyek untuk menghindari identifikasi visual dari odoran. ${ }^{28}$

Dari Tes ini dapat diketahui tiga komponen, yaitu ambang penghidu, diskriminasi penghidu dan identifikasi penghidu. ${ }^{30}$ Untuk ambang penghidu ( $\mathrm{T}$ ) digunakan n-butanol sebagai odoran, yang terdiri dari 16 serial pengenceran dengan perbandingan $1: 2$ dalam pelarut aqua deionisasi. Tes ini menggunakan triple forced choice paradigma yaitu metode bertingkat tunggal dengan 3 pilihan jawaban. Pengujian dilakukan dengan pengenceran n-butanol dengan konsentrasi terkecil. Skor untuk ambang penghidu adalah 0 sampai $16 .^{29,33}$

Untuk diskriminasi penghidu (D), dilakukan dengan menggunakan 3 pena secara acak dimana 2 pena berisi odoran yang sama dan pena ke-3 berisi odoran yang berbeda. Pasien disuruh menentukan mana odoran yang berbeda dari 3 pena tersebut. Skor untuk diskriminasi penghidu adalah 0 sampai $16 .^{31,33}$
Untuk identifikasi penghidu (I), tes dilakukan dengan menggunakan 16 odoran yang berbeda, yaitu jeruk, anis (adas manis), shoe leather (kulit sepatu), peppermint, pisang, lemon, liquorice (akar manis), cloves (cengkeh), cinnamon (kayu manis), turpentine (minyak tusam), bawang putih, kopi, apel, nanas, mawar dan ikan. Untuk satu odoran yang betul diberi skor 1, jadi nilai skor untuk tes identifikasi penghidu adalah 0-16. Interval antara pengujian minimal 20 detik untuk proses desensitisasi dari nervus olfaktorius. $^{29,30}$

Untuk menganalisa fungsi penghidu seseorang digunakan skor TDI yaitu hasil dari ketiga jenis tes "Sniffin Sticks", dengan antara skor 1sampai 48, bila skor $\leq 15$ dikategorikan anosmia, 16-29 dikategorikan hiposmia, dan $\geq 30$ dikategorikan normosmia. ${ }^{31}$ Tes ini menggambarkan tingkat dari gangguan penghidu, tapi tidak menerangkan letak anatomi dari kelainan yang terjadi. $^{11}$

Odoran yang terdapat dalam tes "Sniffin Sticks" adalah odoran yang familiar untuk negara eropa, tapi kurang familiar dengan negara lain. Hal ini dapat diatasi dengan memberikan istilah lain yang familiar untuk odoran tersebut. ${ }^{34}$ menurut Shu ${ }^{35}$ tes "Sniffin Sticks" dapat digunakan pada penduduk Asia.

4. Tes Odor Stick Identification Test for Japanese (OSIT-J).

OSIT-J terdiri dari 13 bau yang berbeda tapi familiar dengan populasi Jepang yaitu condessed milk, gas memasak, kari, hinoki, tinta, jeruk Jepang, menthol, parfum, putrid smell, roasted garlic, bunga ros, kedelai fermentasi dan kayu. Odoran berbentuk krim dalam wadah lipstik. Pemeriksaan dilakukan dengan mengoleskan odoran pada kertas parafin dengan diameter $2 \mathrm{~cm}$, untuk tiap odoran diberi 4 pilihan jawaban. Hasil akhir ditentukan dengan skor OSIT-J. ${ }^{36}$

E. Pemeriksaan elektrofisiologis fungsi penghidu. Pemeriksaan ini terdiri dari Olfactory EventRelated Potentials (ERPs), dan Elektro-Olfaktogram (EOG). 2,13,21

1. Olfactory Event - Related Potentials (ERPs). ERPs adalah salah satu pemeriksaan fungsi penghidu dengan memberikan rangsangan odoran intranasal, dan dideteksi perubahan pada elektroencephalography (EEG). Rangsangan odoran untuk memperoleh kemosensori ERPs harus dengan konsentrasi dan durasi rangsangan yang tepat. Waktu rangsangan yang diberikan antara 1-20 mili detik. Jenis zat yang digunakan adalah vanilin, phenylethyl alkohol, dan $\mathrm{H}_{2} \mathrm{~S}^{2,22}$

2. Elektro-Olfaktogram (EOG).

Pemeriksaan ini dilakukan dengan menempatkan elektroda pada permukaan epitel penghidu dengan tuntunan endoskopi. Kadang pemeriksaan ini kurang nyaman bagi pasien karena biasanya menyebabkan bersin pada waktu menempatkan elektroda di regio olfaktorius dihidung. 2,16

F. Biopsi neuroepitel olfaktorius.

Biopsi neuroepitel olfaktorius berguna untuk menilai kerusakan sistem penghidu. Jaringan diambil dari septum nasi superior dan dianalisis secara histologis. Pemeriksaan ini jarang dilakukan karena invasif. $^{2}$

\section{KESIMPULAN}

1. Fungsi penghidu pada manusia memegang peranan penting. 
2. Area penghidu terdapat di atap rongga hidung, yaitu di neuroepitel olfaktorius, sinyal diteruskan ke bulbus olfaktorius dan korteks olfaktorius di otak.

3. Penyebab gangguan penghidu adalah gangguan transpor, gangguan sensoris, dan gangguan neural/saraf.

4. Penyakit yang sering menyebabkan gangguan penghidu adalah rinosinusitis kronis, rinitis alergi, infeksi saluran nafas atas dan trauma kepala.

5. Pemeriksaan kemosensoris untuk gangguan penghidu ada beberapa macam, diantaranya tes UPSIT (University of Pennsylvania Smell Identification), tes The Connectitut Chemosensory Clinical Research Center (CCCRC), tes "Sniffin Sticks" dan Odor Stick Identification Test for Japanese (OSIT-J).

6. Kelebihan tes "Sniffin Stick" dibandingkan pemeriksaan kemosensoris penghidu lainnya adalah tes ini dapat menentukan ambang penghidu, diskriminasi penghidu dan Identifikasi penghidu. Test ini sudah dipakai pada lebih dari 100 penelitian yang sudah dipublikasikan. Tes ini telah diteliti dapat digunakan di negara lain termasuk di Asia.

\section{DAFTAR PUSTAKA}

1. Einbenstein $A$, Fiorini $A B$, Lena $C$, Rosati $N$, Oktaviano I, Fuseti M. olfactoryscreening test: exerience in 102 Italian subjects. Acta Otorhinolaringol 2005; 25: 18-22.

2. Doty RL, Bromley SM, Panganiban WD. Olfactory function and disfunction. In: Bailey BJ, Johnson JT, Newlands SD, editors. Head and Neck Surgery Otolaryngology. $4^{\text {th }}$ ed. Philadelphia: Lippincott William \& Wilkins; 2006. p. 290-305.

3. Gaines GA. Anosmia and hyposmia. Allergy Asthma Proc 2010; 31: 185-9.

4. Hummel T, Lotsch J. Prognostic factor of olfactory dysfunction. Arch Otolaryngol Head neck surg 2010; 134(4): 347-51.

5. Hummel T, Nordin S. Smell loss, sosi white paper: Quality of live in olfactory disfunction. Available from http: //www. senseofsmell. org/ smell- losswhitepaper-full. Php\#olfactoryfunction

6. Fortin A, Levebvre MB, Ptitto M. Traumatic brain injury and olfactory deficits: The tale of two test Brain Injury 2010; 24(1): 2-33.

7. Mueller CA, Grasinger E, Naka A, Temmel AFP, Hummel T, Kobal G. A self administered odor identification test procedure using the "sniffin sticks". Chem Senses 2006; 31: 595-98.

8. Doty RL, Mishra A. Olfaction and its alteration by nasal obstruction, rhinitis, rhinosinusitis. The laryngoscope 2001; 14: 409-23.

9. Ganong WF. Smell and taste. In Review of medical physiology. $20^{\text {th }}$ ed. San Fransisco: Medical Publishing Division; 2001. p. 340-7.

10. Ballenger JJ. Hidung dan sinus paranasal. Dalam: Ballenger JJ, alih bahasa FKUI. Penyakit Telinga Hidung Tenggorok Kepala \& Leher. Jilid 1. Jakarta: Bina Rupa Aksara; 2002. Hal 1-27.

11. Raviv JR, Kern RC. Chronic Rhinosinusitis and olfactory dysfunction. In: Hummel T, Lussen AW, editors. Taste and smell. Vol 63. Switzerland: Karger; 2006. p. 108-24.

12. Despopulous A, Silbernagl. Central nervous system and senses in color atlas of physiology. $5^{\text {th }}$ ed. New York: Thieme; 2003. p. 340-41.
13. Rawson NE, Yee KK. Transduction and coding. In: Hummel T, Lussen AW, editors. Taste and smell. Switzerland: Karger; 2006. p. 23-43.

14. Wrobel BB, Leopold DA. Olfactoryand sensory attributes of the nose. Otolaryngol Clin N Am 2005; 38: 1163-70.

15. Soetjipto D, Wardhani S. Sumbatan hidung. Dalam: Soepardi EA, Iskandar N, Bashiruddin J, Restuti RD, editor. Buku Ajar IImu Kesehatan Telinga Hidung Tenggorok Kepala \& Leher. Edisi ke 6. Jakarta: Balai Penerbit Fakultas Kedokteran Indonesia; 2007. Hal 118-37.

16. Rouby C, Danguin TT, Vigouroux M, Ciuperca G, Jiang $\mathrm{T}$, Alexanian $\mathrm{J}$, et all. The lyon clinical olfactory test: Validation and measurement of hyposmia and anosmia in healthy and diseased population. International Journal of otolaryngology $2011 ; 23: 1-9$

17. Simmen D, Briner HR. Olfaction in rhinologymethods of assesing the sense smell. Rhinology 2006; 48: $\quad$ 98-101.

18. Lussen AW, Wolsfenberger M Olfactory disorder following upper respiratory tract infection. In: Hummel T, Lussen AW, editors. Taste and smell. Switzerland: Karger; 2006. p. 125-32.

19. Costanzo RM, Miwa T. Post traumatik olfactory loss. In: Hummel T, Lussen AW, editors. Taste and smell. Switzerland: Karger; 2006. p. 99-107.

20. Chang $\mathrm{H}$, Lee $\mathrm{HJ}$, Mo JH, Lee $\mathrm{CH}$, Kim JW. Clinical implication of the olfactory cleft in patient with chronic rhinosinusitis and olfactory loss 2009; 135(10): 988-92.

21. Guilermany JM, Pinero AG, Alobid I, Cardelus S, Centellas S, Bartra J et all. Persistent allergic rhinitis has moderate impact on the sense of smell, depending on both nasal congestion and inflamation. The laryngoscope february 2009; 119(2): $p$ 233-8.

22. Hummel T, luessen AW. Assesment of olfactory function. In: Hummel T, Lussen AW, editors. Taste and smell. Switzerland: Karger; 2006. p. 8498.

23. Boyce JM, Shone GR. Effect of ageing on smell and taste. Postgrad Med J 2006; 82: 239-41.

24. Vent J, Robinson AM, Nielsen G, Conley DB, Hallworth R, Leopold DA et al. Pathology of the olfactory epithelium: smooking and ethanol exposure. Larygoscope 2004; 114(8): 331-4.

25. Tuccori M, Lapi F, Testi A, Ruggiero E, Moretti U, Vannaci $A$, et al. Drug induced taste and smell alterations, a case non case evaluation of an Italian database of spontaneous adverse drug reaction reporting. Drug saf 2011; 34; 849-59.

26. Jiang RS, Su CM, Liang KL, Shiao JY, Wu SH, Hsin CA. A pilot study of a traditional chinese version of the university of pennsylvania smell identification test for aplication in taiwan. American Journal of Rhinology and Allergy 2010; 24(1): 45-50.

27. Vallecillo MVS, Fraire ME, Cagnani CB, Zernotti ME. Olfactory disfunction in patient with cronic rhinosinusitis. International journal of otolaringology 2012; Article ID 32206: 1-5.

28. Yanez DJ, Toledano A, Serrano E, Rosales M, Rodriquez EB, Varona P. Characterization of a clinical olfactory test. Available from http://www.frontiersin.org/Neurengineering/10.338 9/fneng.2012.00001/full 
29. Hummel T, Kobal G, Gudziol H, Mackay A. Normative data for the "sniffin sticks" including test of odor identification, odor discrimination, and olfactory thresholds: an upgrade based on a group of more than 3,000 subjects. Eur Arch otorhinolaryngol 2007; 264 : 23-43.

30. Lotsch J, Lange C, Hummel T. A simple and reliable method for clinical assessment of odor tresholds. Chen Senses 2004; 29: 311-17.

31. Lay AM, McGinlay CM. A nasal chemosensory performance test for odor inspectors. Lake elmo; St Croix Sensory Inc 2004

32. Product catalog "Sniffin Sticks". Available from http://www.burghart-mt.de/

33. Hummel T, Sekinger B, Wolf SR, Pauli E, Kobal G. "Sniffin sticks: Olfactory performance assessed by the combined testing of odor identification, odor discrimination and olfactory treshold. Chem Senses 1997; 22(1): 39-52
34. Catana J, Negoias S, Maniu A, Parojan M, Cosgarea M. A modified version of Sniffin sticks odor identification test: The Romanian cultural adaptation. Otorinolaringologie Clujul medical 2012; 85: 211-6.

35. Shu CH, Yuan BC, Lin SH, Lin CZ. Cross cultural aplication of the Sniffin Sticks odor Identification test 2007; 21: 570-3.

36. Kobayashi M, Reiter ER, Dinardo LJ, Costanzo RM. A new clinical olfactory function test. Arch Otolaryngol Head neck surg 2007; 133: 331-6. 